\title{
Modelling and multi-scenario analysis for electric heat tracing system combined with low temperature district heating for domestic hot water supply
}

\author{
Yang, Xiaochen; Li, Hongwei; Svendsen, Svend
}

Published in:

Building Simulation

Link to article, DOI:

10.1007/s12273-015-0261-4

Publication date:

2016

Document Version

Peer reviewed version

Link back to DTU Orbit

Citation (APA):

Yang, X., Li, H., \& Svendsen, S. (2016). Modelling and multi-scenario analysis for electric heat tracing system combined with low temperature district heating for domestic hot water supply. Building Simulation, 9(2), $141-151$. https://doi.org/10.1007/s12273-015-0261-4

\section{General rights}

Copyright and moral rights for the publications made accessible in the public portal are retained by the authors and/or other copyright owners and it is a condition of accessing publications that users recognise and abide by the legal requirements associated with these rights.

- Users may download and print one copy of any publication from the public portal for the purpose of private study or research.

- You may not further distribute the material or use it for any profit-making activity or commercial gain

- You may freely distribute the URL identifying the publication in the public portal 


\begin{abstract}
Low-temperature district heating (LTDH) is a cost-efficient way of supplying space heating and domestic hot water (DHW) for buildings in urban areas. However, there is concern about the potential hygiene problems (Legionella) might occur if LTDH is implemented, especially for large buildings. In this study, electric heat tracing system was investigated as a solution to this dilemma. A model of electric heat tracing system for multi-storey buildings was built. Various pipe materials and insulation thicknesses as the parameters of the model were compared to make a comprehensive study. The performance of the electric heating tracing system with LTDH was simulated by taking the user pattern into account. A smart control method based on thermostatic and real-time control was developed, and compared with normal control method. The impact of user pattern was tested by applying standard, stochastic, and real load profiles to the model. The energy and economy performances of electric heat tracing system under different scenarios were simulated by Matlab. The results were compared to the conventional circulation system with the current generation district heating. The electric heat tracing system with LTDH showed good performance on heat loss saving, and it also gave benefits to district heating network by sharing part of the heating load.
\end{abstract}

\title{
List of symbols
}

$U_{\text {pipe }}$ is the heat loss coefficient of the pipe $[W /(m \cdot K)]$,

$a_{i}$ is the internal heat transfer coefficients $\left[W /\left(m^{2} \cdot K\right)\right]$,

$a_{e}$ is the external heat transfer coefficient $\left[W /\left(m^{2} \cdot K\right)\right]$,

$D_{1}$ is the inner pipe diameter $[m]$, 
$D_{2}$ is the outer pipe diameter $[m]$,

$D_{3}$ is the outer diameter of the insulation $[m]$,

$\lambda_{\text {pipe }}$ is the thermal conductivity of the pipe material $[\mathrm{W} /(\mathrm{m} \cdot \mathrm{K})]$,

$\lambda_{\text {insulation }}$ is the thermal conductivity of the insulation $[\mathrm{W} /(\mathrm{m} \cdot \mathrm{K})]$, which is $0.037 \mathrm{~W} /(\mathrm{m} \cdot \mathrm{K})$ in this case (Rockwool(2014b) 2014).

$Q_{H L}$ is the heat loss [W],

$I_{i}$ is the length of each pipe segment $[\mathrm{m}]$,

$T_{\text {flow }}$ is the average temperature of the supply pipe $\left[{ }^{\circ} \mathrm{C}\right]$,

$T_{a m b}$ is the ambient temperature $\left[{ }^{\circ} \mathrm{C}\right]$.

$P$ is the power rate of the electric cable $[\mathrm{W} / \mathrm{m}]$,

$\tau$ is the working time $[\mathrm{s}]$,

$Q_{h}$ is the energy for heating up DHW $45-55^{\circ} \mathrm{C}[\mathrm{J}]$

$Q_{1}$ is the heat loss [J]

$C_{p}$ is the heat capacity of the water $[\mathrm{J} /(\mathrm{kg} \cdot \mathrm{K})]$,

$m$ is the mass of water $[\mathrm{kg}]$,

$q_{\text {l }}$ is the heat loss rate $[\mathrm{W} / \mathrm{m}]$, 
$E$ is integral electricity consumption,

$H L$ is integral heat loss,

$t$ is the length of interval period,

$q_{1}\left(55^{\circ} \mathrm{C}\right)$ is the heat loss rate at $55^{\circ} \mathrm{C}$,

a $n n$ means annually.

\section{Keywords}

Low temperature district heating; domestic hot water; electric heat tracing; user pattern profile; smart $\underline{\text { control modelling; Legionella prevention }}$

\section{Introduction}

\subsection{Low-temperature district heating}

Energy consumption for heating accounts for a large proportion of the overall building energy consumption, especially in cold regions, like Scandinavia. One efficient way to supply heat to areas with high heat density is district heating (Reidhav and Werner 2008). Currently, 50\% of residential buildings in Denmark are heated by district heating (Grontmij 2013), and it is planned to expand this to $70 \%$ by 2035 (Dyrelund et al. 2010). It is important to make district heating more competitive and energy-efficient, so novel concepts should be implemented, such as the new low-temperature district heating (the $4^{\text {th }}$ generation of district heating (Lund et al. 2014)).

Low-temperature district heating has many advantages such as less heat loss in heat distribution networks, higher utilization of renewable energy sources (such as solar and geothermal), higher power-to-heat ratio in the steam CHP plants, better recovery for waste heat from flue gas 
condensation, and easier maintenance. Currently, most European countries use $80{ }^{\circ} \mathrm{C} / 40{ }^{\circ} \mathrm{C}$ as supply and return temperatures for district heating. However, the aim is to lower the supply/return temperatures to $55^{\circ} \mathrm{C}$ and $25^{\circ} \mathrm{C}$ respectively. As a result, the efficiency of both heat production and network can be improved significantly.

\subsection{Prevention for Legionella in domestic hot water systems}

One issue that prevents the application of LTDH is the concern of proliferation of Legionella in DHW system. The genus Legionella is a group of gram-negative bacteria that mainly exist in aquatic environments. People can become infected by inhaling an aerosol with a high concentration of Legionella if the domestic hot water system is contaminated. The most suitable proliferation temperature is in the range from $25{ }^{\circ} \mathrm{C}$ to $45^{\circ} \mathrm{C}$ (van der Kooij et al. 2005). Long residence time (stagnancy) and a nutrition source (such as biofilm and sediments) also play important roles in the multiplication of Legionella (Ciesielski et al. 1984). Consequently, large hot water systems with low operating temperatures have a high risk of contamination. Many countries therefore have strict rules for domestic hot water temperatures. EU guidelines state that all water heaters should deliver water at a temperature of at least $60^{\circ} \mathrm{C}$, reaching taps at no less than $55^{\circ} \mathrm{C}$ after 1 min of flushing ( EWGLI group 2005). In Denmark, DHW temperature has to be maintained at $50{ }^{\circ} \mathrm{C}$ during normal use and no less than $45^{\circ} \mathrm{C}$ at peak loads according to the comfort requirement in DS 439, while the CEN/TR standard 16355, which is for prevention of Legionella, recommends the hot water temperature should reach $55^{\circ} \mathrm{C}$ in the whole system (DS439 2009; DS/CEN/TR16355 2012).

Thus, a solution that can supply DHW with LTDH and without violating any comfort requirements or hygiene requirements is urgently needed.

\subsection{Electric heat tracing}


As mentioned above, low-temperature district heating will be promoted in the future due to its prominent advantages. However, the temperature of domestic hot water cannot achieve the recommended $55^{\circ} \mathrm{C}$ if the supply temperature from the district heating network is lower than that. Conventionally, to provide DHW to multi-storey buildings within an acceptable waiting time (10s), DHW circulation is required. Therefore, to avoid Legionella, the DHW circulation should be operated at 55 oC. However, a previous investigation in Denmark found that much of the energy was lost in the circulation process, which leads to the heating system having a very low efficiency (approx. $30 \%-77 \%$ ) (Bøhm 2013). Another method is to use supplementary heating devices to keep domestic hot water supply at the required temperature. Electric heat tracing can be used for such concept.

The method is to use an electrical cable in thermal contact with the entire length of the external surface of the supply pipe, thereby heating up the supply pipe by electric power. Thus no circulation pipe is necessary, saving both pump cost and space. The overall heat loss is also reduced by removing the circulation pipe.

The application of electric heat tracing in industrial field has been well documented, such as process plants and offshore oil or gas equipment. However, the application to residential building has been insufficiently studied. Compared to industrial electric heat tracing systems, the control method required for residential buildings is complex, because the use of domestic hot water is not continuous and can vary due to different user patterns. One of the very few reported real case studies is an electric heat tracing system installed in Aalborg Hospital to deal with a Legionella problem. The operational cost of the new electric heat tracing system was only half that of the circulation system it replaced. The report states that the energy used by the electric heat tracing system could be further reduced by $30-40 \%$ if real consumption pattern was taken into account (Olsen 2001). 
This study set out to deal with the dilemma between low temperature district heating and the risk of legionella, by developing a dynamically controlled model of an electric heat tracing system as an alternative solution for existing multi-storey buildings, especially where deep renovation is difficult. The model took the complex use pattern of multi-residence building into account, which has not been studied before. The energy consumption and cost for DHW production with both normal control and smart control were compared with that of the conventional system with DHW circulation. The dynamic working characteristics of the cable were taken into consideration, so that the tracing cable was not just maintained at the set point temperature, but could respond instantly to every draw-off of the consumer, thereby achieving thermal comfort and effectively avoiding unnecessary heat loss at high temperatures. Three DHW load profiles from European directive, computer generation and a practical case were input to the model to investigate the impact of the user patter on the total heat consumption.

\section{Methodology}

\subsection{Model building and system dimensioning}

The theoretical building used in this study was defined as a typical Nordic building stock. It was a 6-storey building with three blocks (staircases). There were two apartments on each floor in each block, all with the same internal structure and floor area $\left(100 \mathrm{~m}^{2}\right)$. All three building blocks shared a central district heating substation in the basement, where the supply heat from the district heating network was transferred to the building's space heating and DHW loops. The air temperature was assumed to be $10{ }^{\circ} \mathrm{C}$ in the basement and $20^{\circ} \mathrm{C}$ in the rest of the building. The height of each storey was $3 \mathrm{~m}$, and the distance between staircases was $20 \mathrm{~m}$.

\subsection{System description}


Simplified diagrams of a conventional system with in-line circulation and an electric heat tracing system are shown in Figure 1Figure 1 (a) and (b) respectively.

\begin{tabular}{|c|c|c|c|c|c|}
\hline $\begin{array}{l}\text { A District heating supply/return } \\
\text { pipe }\end{array}$ & 木 & 木 & 木 & 木 & 木 \\
\hline $\begin{array}{l}\text { B Space heating supply/return } \\
\text { pipe }\end{array}$ & 木 & 木 & 木 & 木 & 木 \\
\hline C DHW supply pipe & 木 & $\pi$ & $\pi$ & $\pi$ & $\pi$ \\
\hline $\begin{array}{l}\text { D Domestic cold water pipe } \\
\text { E In-line circulation pipe }\end{array}$ & 小 & & 小 & & 小 \\
\hline $\begin{array}{l}1 \text { Heat exchanger for DHW loop } \\
2 \text { DHW faucet in the flat }\end{array}$ & $\pi$ & 木 & 木 & 木 & 木 \\
\hline 3 Circulation pump & 木 & $\pi$ & $\pi$ & $\pi$ & $\pi$ \\
\hline$R$ & 木 & 木 & 木 & $\pi$ & 木 \\
\hline
\end{tabular}

(a)

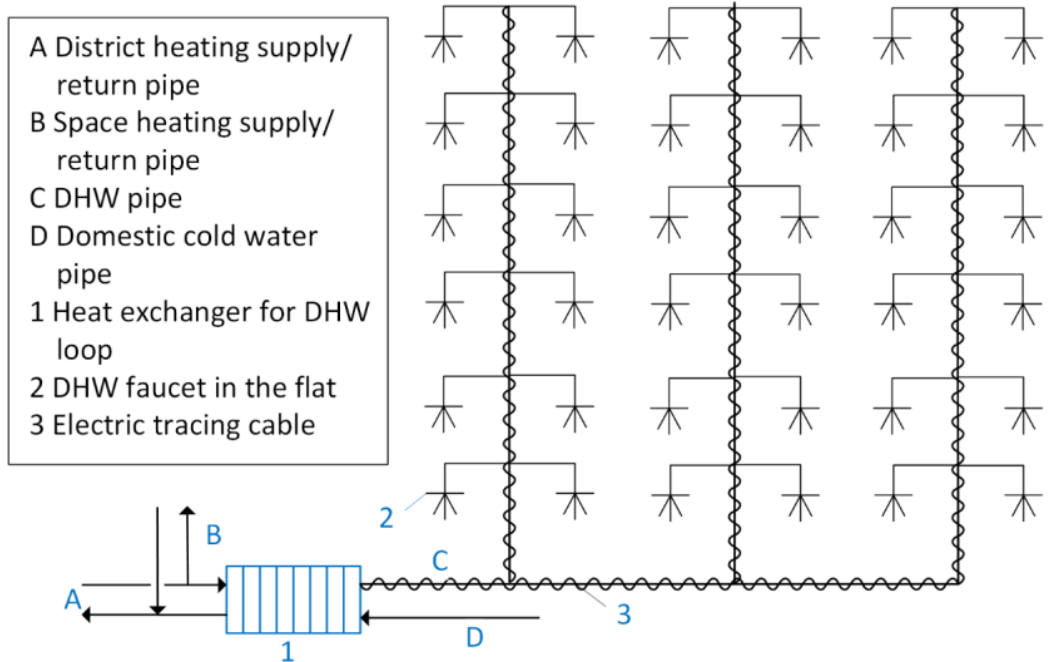

(b)

Figure 1 Schematics of conventional system with DHW circulation and electric heat tracing system 
For both the in-line circulation system and the electric heat tracing system, the space heating and DHW were supplied by district heating, but in separated loops. As the reference case, an "in-line circulation" system was designed as shown in Figure 1Figure 1 (a). To provide hot water for domestic use, the domestic cold water is heated up in the central substation firstly, and then distributed to the consumers. To meet the comfort requirement, hot water circulation is necessary if there is no supplementary heating devices. In this study, the in-line circulation system is used for analysis, which has the circulation pipe goes through the supply riser, thereby reducing the temperature drop for the circulation pipe. The external supply pipe was made of stainless steel, and the internal circulation pipe was made of PEX. The pipe dimensions were selected by reference to existing product catalogue (Viega 2014).

For the electric heat tracing system, the schematic is shown in Figure 1Figure 1(b). The DHW was firstly heated up by the LTDH in the central substation. The electric heat tracing cable was used for supplementary heating and maintaining the temperature of DHW supply pipe. The control methods play an important role in the performance of the tracing cable. In this study, two control methods were applied in the dynamic model of electric heat tracing system. To provide a more comprehensive study, two common pipe materials (stainless steel and PEX) and two insulation classes (normal and plus) were selected. The specific pipe dimensions were found by reference (Geberit 2014; Uponor 2006). The insulation thickness was chosen in accordance with DS 452 and technical handbook (DS452 2013; Rockwool(2014a) 2014; Rockwool(2014b) 2014) for corresponding situations.

\subsection{Operating temperatures}

The control temperatures in this study was chosen carefully in accordance with the standards for comfort and hygiene supply of DHW (DS439 2009; DS/CEN/TR16355 2012). The system was designed to be able to supply $55^{\circ} \mathrm{C}$ at any point most of time, and no lower than $45^{\circ} \mathrm{C}$ during a draw- 
off period. For the in-line circulation system, to ensure the whole system can achieve $55^{\circ} \mathrm{C}$, the DHW was assumed to be produced around $60^{\circ} \mathrm{C}$. Therefore, the mean temperature of the in-line pipe (pipein-pipe) was assumed to be $57{ }^{\circ} \mathrm{C}$, and was kept circulating all the time. For the electric heat tracing system, hot water was assumed to be heated to $45^{\circ} \mathrm{C}$ by the district heating network, but the tracing cable had the capacity to heat up DHW from $45{ }^{\circ} \mathrm{C}$ to $55^{\circ} \mathrm{C}$. Thus, the temperature requirements for both systems were guaranteed.

\subsection{Smart control for electric heat tracing system based on load profile}

The electric heat tracing system was simulated under both normal control and smart control methods. The normal control method mainly refers to self-regulating function, which reduces the heating current as the desired temperature is approached and delivers the appropriate amount of heat at every point along the pipe. Therefore, different cable segments could have different power rates. The on/off function can help maintain the cable at set point temperature. However, normal control method cannot response to the various tapping pattern. Therefore, this study developed a more sensitive and smart control method based on DHW load profiles. The on/off switch of the cable was not only controlled by the temperature set band, but also by each draw-off on the consumer side. 


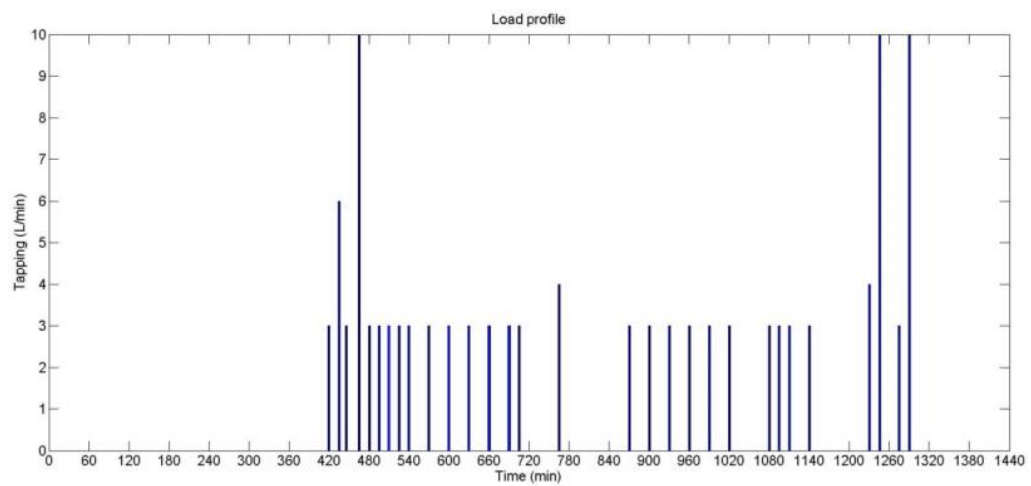

Figure 2 Typical load profile of European flats from EU directive (Commission Delegated Regulation (EU) of 18.2.2013 2013)

Figure 2Figure 2 shows the typical load profile of European flats in a multi-storey building. The smart control system is able to detect the start and the end point of each draw-off from the temperature difference. Temperature sensors and thermostats were installed on each floor, so that, no matter which floor reached $55^{\circ} \mathrm{C}$, the cable segment was able to adjust individually without affecting other floors. During the draw-off period, the tapping water can achieve $45^{\circ} \mathrm{C}$ by the LTDH supply, the pipe segments from the basement to the tapping point is flushed with $45^{\circ} \mathrm{C}$ hot water. Therefore, the cable segments from the basement to the tapping-point floor were switched off. At the end of the tapping, the cable is switched on to heat up the DHW through the interval between the draw-offs. So that the DHW temperature can be ensured to be no less than $45{ }^{\circ} \mathrm{C}$, and the multiplication of Legionella is avoided. For non-tapping periods long enough to lift the temperature to $55^{\circ} \mathrm{C}$, the thermostat reduces the cable power rate to compensate only for the heat loss rate as soon as $55^{\circ} \mathrm{C}$ is reached and maintains this temperature until the next draw-off. This means that the total power consumption of the cable is determined by the load profile. Draw-offs can be divided into four types, each with their own flow rates and tapping lengths as shown in Table 1Table 1, which is defined in DS 439 (DS439 2009). Thereby, the tapping periods and non-tapping periods of a certain load profile can be calculated. 
Table 1 Period length and flow rate of different types of draw-off

\begin{tabular}{ccccc}
\hline & Hand Washing & Kitchen & Shower & Bathtub \\
\hline Period $(\min )$ & 3 & 2.5 & 5 & 10 \\
Flow rate $(\mathrm{L} / \mathrm{min})$ & 3 & 6 & 8.4 & 12 \\
\hline
\end{tabular}

For the normal-control method in this study, the only temperature sensor was installed in the ground floor, which means that the cable power rate can be reduced to the heat loss rate only if the temperature of the ground floor reached $55^{\circ} \mathrm{C}$. The other parts of the cable were adjusted by the selfregulation function. Since whole cable followed the pattern of the ground floor, some pipe segments could become overheated. To avoid scalding problems, thermostatic water mixers are required.

Three load profiles were applied in this study to investigate the influence on different control methods. Load profile 1 was based on the standard user pattern in Figure 2Figure 2. It was assumed to be an extreme scenario, in which all the consumers used hot water following the same hot water consumption pattern at the same time.

Load profile 2 was also based on the standard load profile. All the consumers followed the same pattern of using domestic hot water, but the start points of different flats were distributed along the timeline stochastically by the computer. Considering the diversity of DHW use in large buildings, it was assumed that there was no overlap on the first draw-off between different apartments in the same building block. Figure 3Figure 3 shows one day's domestic hot water use on each floor of one building block as generated by the computer. 

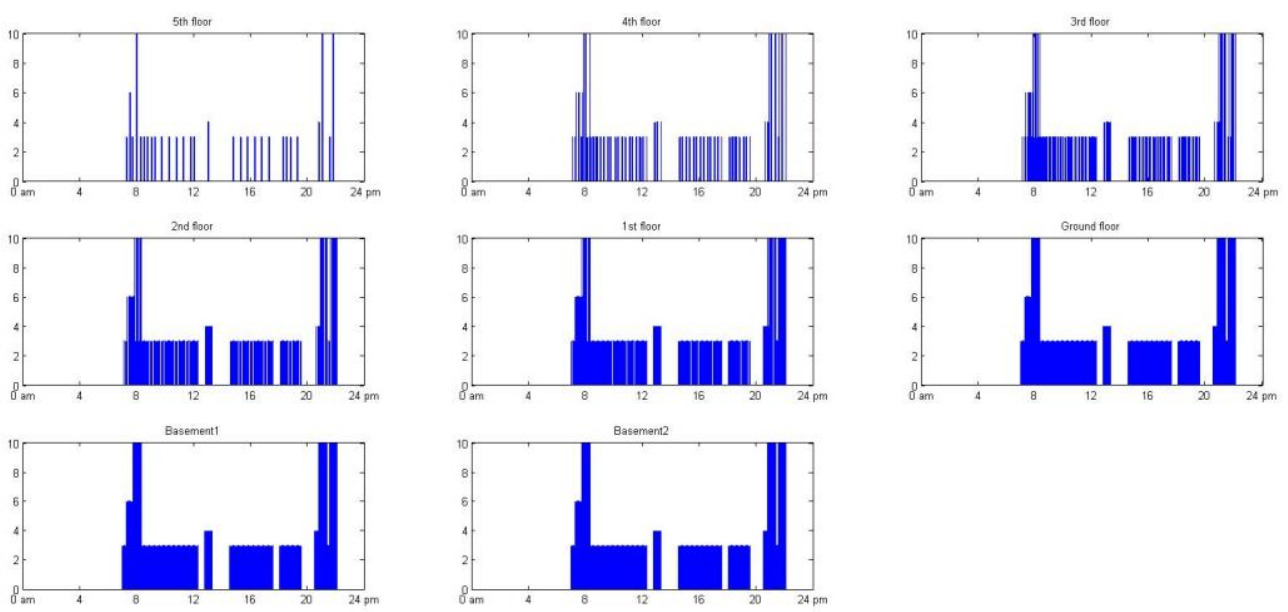

Figure 3 Stochastically-distributed load profile with time (hr) and flow rate (L/min)

Load profile 3 was based on practical load profile measured from a residential multi-storey building in Denmark. The data was collected for a one-day period from 12 am on the $28^{\text {th }}$ to 12 am on the $29^{\text {th }}$ August 2014, with a time step of approximately 0.5 hour. Figure 4Figure 4 shows the measurements of the one-day draw-off profile. 

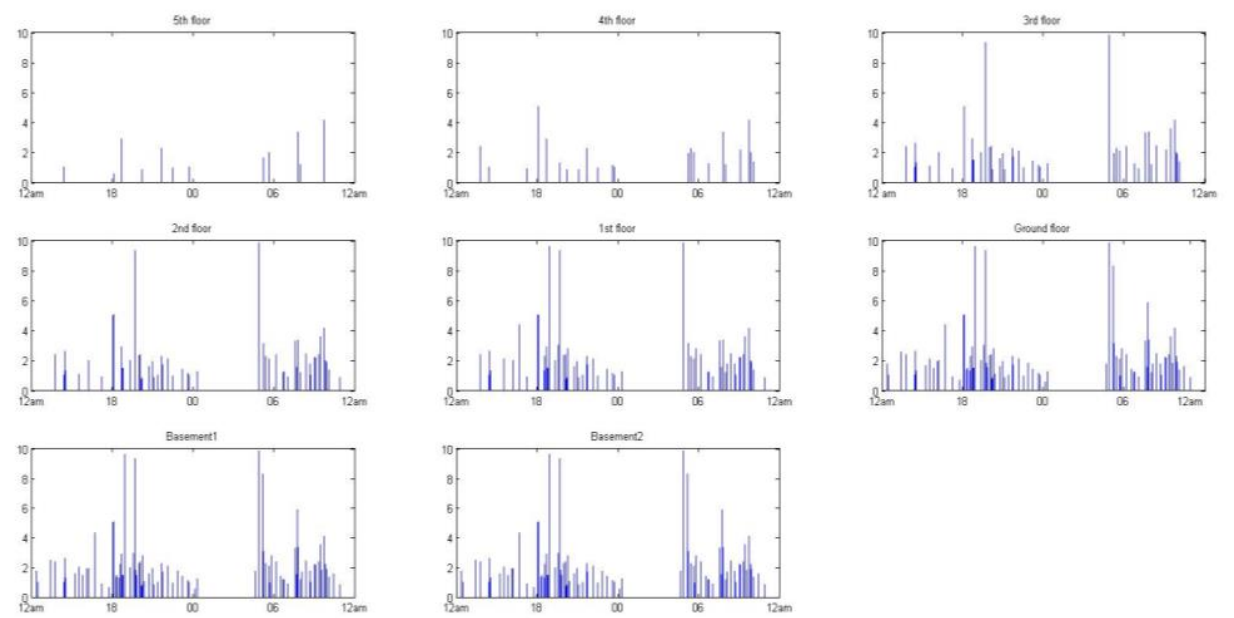

Figure 4 Draw-off measurements in a Danish multi-storey building with time (hr) and flow rate (L/min)

\subsection{Computation for energy performance}

\subsubsection{Heat loss of pipe system}

According to the heat transfer equation, the heat loss coefficient of the pipe can be calculated by Eq.

(1)

$$
\begin{gathered}
U_{\text {pipe }}=\pi \cdot\left(\frac{1}{\alpha_{i} \cdot D_{1}}+\frac{1}{2 \cdot \lambda_{\text {pipe }}} \cdot \ln \left(\frac{D_{2}}{D_{1}}\right)+\frac{1}{2 \cdot \lambda_{\text {insulation }}} \cdot \ln \left(\frac{D_{3}}{D_{2}}\right)+\frac{1}{\alpha_{e} \cdot D_{3}}\right)^{-1} \\
q_{l}=U_{i} \cdot l_{i} \cdot\left(T_{\text {flow }}-T_{\text {amb }}\right)
\end{gathered}
$$

\subsubsection{Power consumption for electric heat tracing}

The energy conservation equation for electric tracing can be written as

$$
P \cdot \tau=Q_{h}+Q_{l}
$$




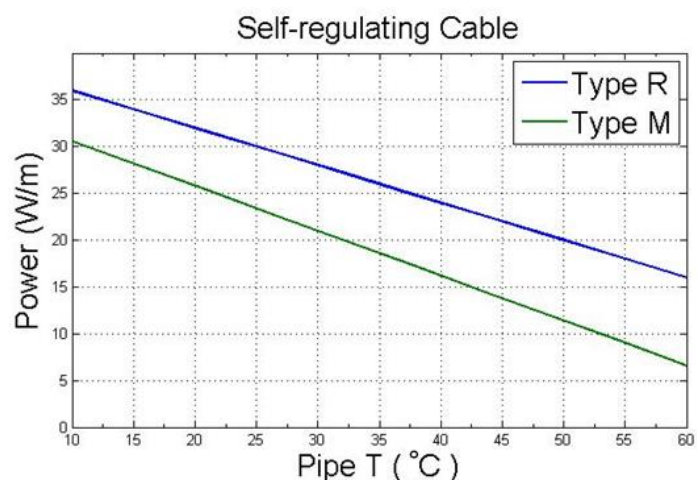

Figure 5 Self-regulation function of the electric tracing cables

For self-regulating cables, the power consumption is proportional to the pipe temperature, which leads to reduced electricity consumption and more precise control. Two types of cable (R and $\mathrm{M}$ ) were applied to the model. The correlation between the pipe temperature and cable power is linear between $10^{\circ} \mathrm{C}$ and $60^{\circ} \mathrm{C}$, as shown in Figure 5Figure 5. Both cable power and heat loss are functions of temperature $(\mathrm{T})$ and time $(\tau)$. Equation (3) can therefore be converted into a differential equation in terms of temperature and time,

$$
P(T) \cdot d \tau=C_{p} \cdot m \cdot d T / 3600+q_{l}(T) \cdot d \tau
$$

Since the required power rate varies with pipe size, the heat-up time for different pipe segments can be calculated by using Equation (5)

$$
\tau=\int_{T 1}^{T 2} \frac{\left(C_{p} \cdot m\right) / 3600}{P(T)-q_{l}(T)} d T
$$

where, in this case study, $\mathrm{T} 1=45^{\circ} \mathrm{C}, \mathrm{T} 2=55^{\circ} \mathrm{C}$.

The correlation between cable power and time $(\mathrm{P}(\mathrm{t}))$, heat loss rate and time $\left(\mathrm{q}_{1}(\mathrm{t})\right)$ can also be obtained by regression method from Equations (4) and (5). 


\subsubsection{Simulation model}

The smart control method was developed based on real-time control, which means the tracing cable can response to every variation of the hot water system. The model was proposed by Matlab dynamically. The schematic chart is shown in Figure 6Figure 6. 


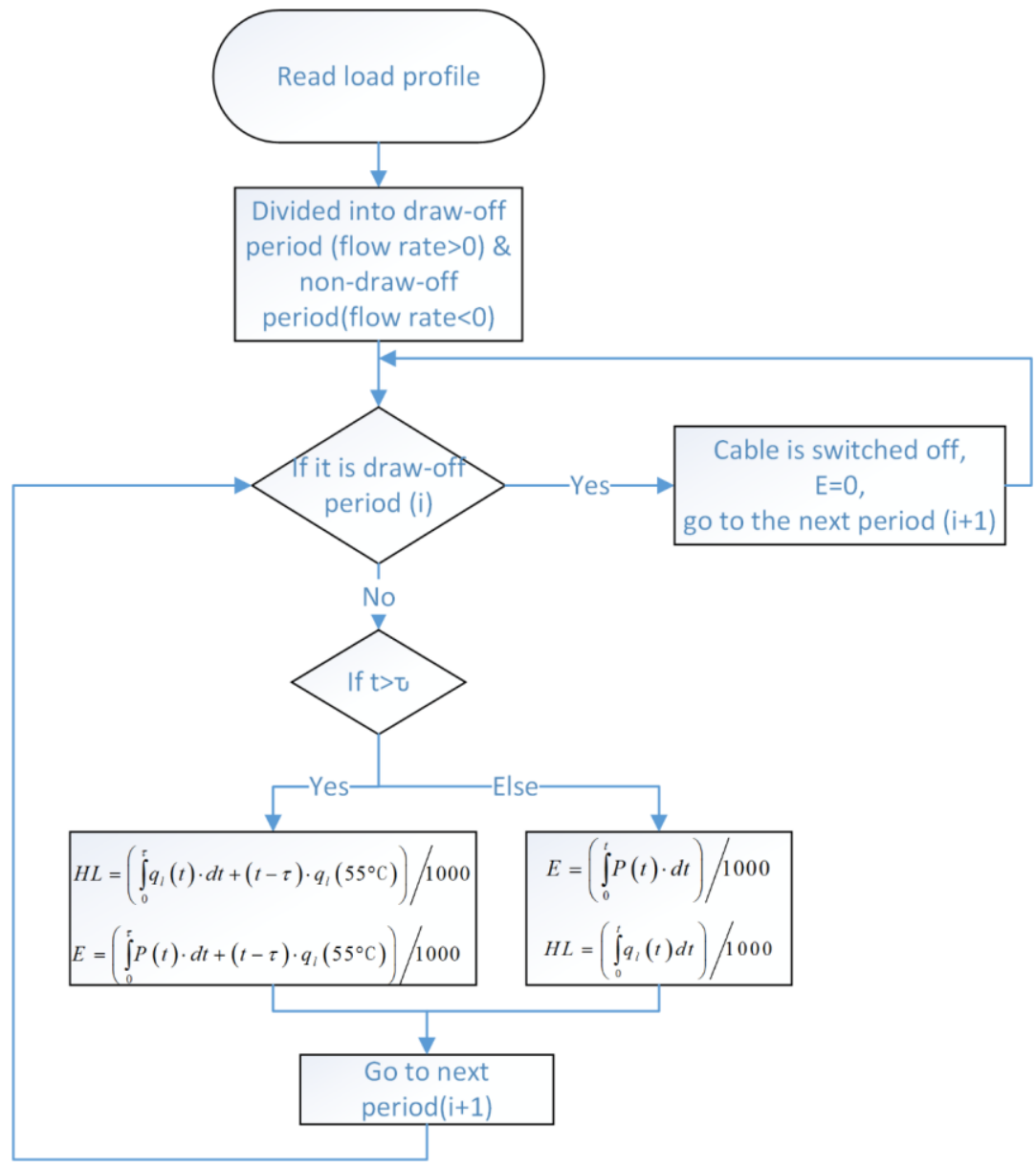

Figure 6 Matlab model of electric tracing system with smart control

The interval length between two draw-offs determined the working time of the tracing cable.

Depending on whether it was longer or shorter than the heat-up time, the electricity consumption and heat loss were calculated by different equations respectively: 


$$
\begin{aligned}
& \mathrm{t}>\tau \quad\left\{\begin{array}{l}
H L=\left(\int_{0}^{\tau} q_{l}(t) \cdot d t+(t-\tau) \cdot q_{l}\left(55^{\circ} \mathrm{C}\right)\right) / 1000 \\
E=\left(\int_{0}^{\tau} P(t) \cdot d t+(t-\tau) \cdot q_{l}\left(55^{\circ} \mathrm{C}\right)\right) / 1000
\end{array}\right. \\
& \mathrm{t}<\tau \quad\left\{\begin{array}{c}
E=\left(\int_{0}^{t} P(t) \cdot d t\right) / 1000 \\
H L=\left(\int_{0}^{t} q_{l}(t) d t\right) / 1000
\end{array}\right.
\end{aligned}
$$

Thus, the performance of the heat tracing system can be simulated dynamically based on specific DHW load profile.

\section{Results and discussion}

\subsection{Pipe dimensions of the case building}

The system dimensions and insulations for different systems are shown in Table 2 and Table 3.

Table 2 Pipe dimensions and insulation of in-line circulation system

\begin{tabular}{ccccc}
\hline Segment & $\begin{array}{c}\text { Apartments } \\
\text { supplied }\end{array}$ & $\begin{array}{c}\text { Exterior pipe } \\
\text { dim. [mm] }\end{array}$ & $\begin{array}{c}\text { Inline pipe } \\
\text { dim. [mm] }\end{array}$ & $\begin{array}{c}\text { Insulation } \\
\text { thickness [mm] }\end{array}$ \\
\hline Basement 1 & 12 & $42 \times 1.5$ & $14 \times 2$ & 30 \\
Basement 2 & 24 & $54 \times 2.0$ & $14 \times 2$ & 40 \\
Ground floor & 12 & $42 \times 1.5$ & $14 \times 2$ & 30 \\
1st floor & 10 & $42 \times 1.5$ & $14 \times 2$ & 30 \\
2nd floor & 8 & $42 \times 1.5$ & $14 \times 2$ & 30 \\
\hline
\end{tabular}




\begin{tabular}{lllll}
\hline 3rd floor & 6 & $42 \times 1.5$ & $14 \times 2$ & 30 \\
4th floor & 4 & $42 \times 1.5$ & $14 \times 2$ & 30 \\
5th floor & 2 & $35 \times 1.5$ & $14 \times 2$ & 30 \\
\hline
\end{tabular}

The outer pipe diameter ranged from $35 \times 1.5 \mathrm{~mm}$ to 54 × $2.0 \mathrm{~mm}$ for the in-line circulation system, while the circulation pipe diameter does not change with the exterior pipe for easier installation and maintenance.

Table 3 Pipe dimension and insulation of electric heat tracing systems

\begin{tabular}{c|ccc|ccc}
\hline \multirow{2}{*}{ Segment } & \multicolumn{3}{c}{ PEX pipes } & \multicolumn{3}{c}{ Stainless steel pipes } \\
\cline { 2 - 7 } & Pipe & Insulation & Insulation & Pipe & Insulation & Insulation \\
& Dimension & Normal & Plus & Dimension & Normal & Plus \\
& {$[\mathrm{mm}]$} & {$[\mathrm{mm}]$} & {$[\mathrm{mm}]$} & {$[\mathrm{mm}]$} & {$[\mathrm{mm}]$} & {$[\mathrm{mm}]$} \\
\hline Basement 1 & $32 \times 4.4$ & 30 & 40 & $28 \times 1.2$ & 30 & 40 \\
Basement 2 & $40 \times 5.5$ & 30 & 50 & $35 \times 1.5$ & 30 & 50 \\
Ground & $32 \times 4.4$ & 30 & 40 & $28 \times 1.2$ & 30 & 40 \\
floor & $32 \times 4.4$ & 30 & 40 & $28 \times 1.2$ & 30 & 40 \\
1st floor & $28 \times 4.0$ & 30 & 40 & $22 \times 1.2$ & 20 & 40 \\
2nd floor & $28 \times 4.0$ & 30 & 40 & $22 \times 1.2$ & 20 & 40 \\
3rd floor & $28 \times 4.0$ & 30 & 40 & $22 \times 1.2$ & 20 & 40 \\
4th floor & $22 \times 3.0$ & 20 & 40 & $18 \times 1.0$ & 20 & 40 \\
5th floor & 28 & & & & & \\
\hline
\end{tabular}


For electric heat tracing, there were four different combinations: two pipe materials and two insulating levels. The heat loss rate of all four combinations were investigated in the following section.

\subsection{Heat loss for different scenarios}

For the in-line circulation system, the heat loss rate and the total energy consumption for distributing DHW in the building was calculated, and the results are shown in Table 4Table 4.

Table 4 Heat loss of in-line circulation system

\begin{tabular}{|c|c|c|c|c|c|c|c|c|}
\hline & Basement1 & Basement2 & $\begin{array}{c}\text { Ground } \\
\text { floor }\end{array}$ & $\begin{array}{c}\text { 1st } \\
\text { Floor }\end{array}$ & $\begin{array}{l}\text { 2nd } \\
\text { Floor }\end{array}$ & $\begin{array}{c}\text { 3rd } \\
\text { Floor }\end{array}$ & $\begin{array}{l}\text { 4th } \\
\text { Floor }\end{array}$ & $\begin{array}{l}\text { 5th } \\
\text { Floor }\end{array}$ \\
\hline $\begin{array}{c}\text { Heat loss rate } \\
\qquad[\mathrm{W} / \mathrm{m}]\end{array}$ & 11.2 & 11.2 & 8.8 & 8.8 & 8.8 & 8.8 & 8.8 & 7.9 \\
\hline $\begin{array}{c}\text { Total heat } \\
\text { loss } \\
\text { [kWh/year] }\end{array}$ & & \multicolumn{7}{|c|}{$\begin{array}{l}\text { Pump power } \\
\text { [kWh/year }]\end{array}$} \\
\hline
\end{tabular}

For the electric heat tracing system, the calculation of heat loss was more complicated. The heat loss rate was not constant because the electric boosting process was dynamic depending on the random load profile. There was also a difference between smart control and normal control. However, the heat loss rate at $55^{\circ} \mathrm{C}$ was calculated for the cable selection. The results are shown in Table 5Fable 5.

Table 5 Heat loss at $55^{\circ} \mathrm{C}$ of electric heat tracing systems with different pipe materials and insulations 


\begin{tabular}{c|cccc} 
& Stainless steel & Stainless steel & PEX & PEX \\
& Normal & Plus & Normal & Plus \\
\hline Basement1 & 8.37 & 7.29 & 8.87 & 7.70 \\
Basement2 & 9.54 & 7.37 & 10.14 & 7.79 \\
Ground floor & 6.51 & 5.67 & 6.90 & 5.99 \\
1st Floor & 6.51 & 5.67 & 6.90 & 5.99 \\
2nd Floor & 6.86 & 5.01 & 6.38 & 5.57 \\
3rd Floor & 6.86 & 5.01 & 6.38 & 5.57 \\
4th Floor & 6.86 & 5.01 & 6.38 & 5.57 \\
5th Floor & 6.12 & 4.55 & 6.73 & 4.94 \\
\hline
\end{tabular}

The heat loss rate of all investigated electric heat tracing systems were much less than that of the inline circulation system, irrespective of the pipe materials used. That is due to the higher mean temperature of the pipe and the larger pipe diameter meant of the in-line circulation system. Moreover, because the circulation pipe was always at a high temperature, the heat losses of the circulation system sometimes even exceeded the net heating demand for DHW.

The floor-based comparison of in-line circulation system and electric heat tracing system is shown in Figure 7Figure 7. 


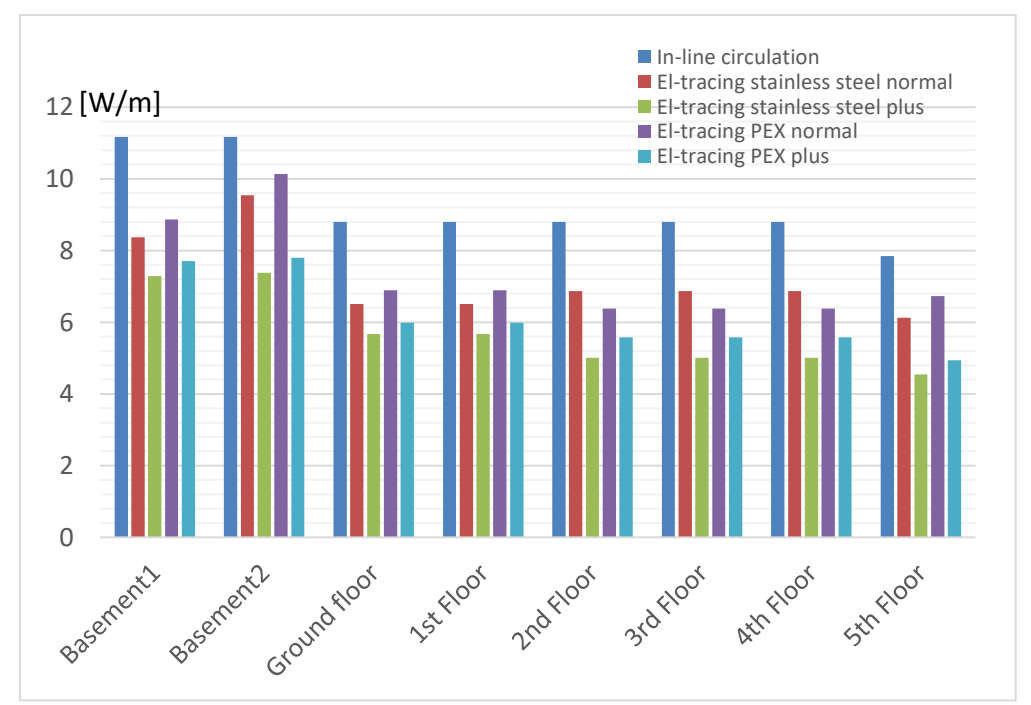

Figure 7 Heat loss rates of in-line circulation system and electric heating tracing systems on different floors

The heat loss rate of the in-line circulation system is the highest for all pipe segments. For the electric heat tracing system, different materials and insulation thicknesses had impacts on the heat loss rate. As showed in Figure 7Figure 7, stainless steel pipes had better performances than PEX pipes with same insulations. Stainless steel pipe with plus insulation had the lowest heat loss. Increasing the insulation thickness by $30 \%-50 \%$, reduced the mean heat loss of stainless pipe by about $21 \%$, while for the PEX pipe the reduction was about $16 \%$. However, increasing the insulation thickness could also increase, the investment cost. It is therefore of great importance to find the optimal insulation thickness, which takes both energy saving and economic performance into account.

\subsection{Selection of the cable for the electric heat tracing system}

The time required for heating up the DHW from $45^{\circ} \mathrm{C}$ to $55^{\circ} \mathrm{C}$ was calculated for both Cable R and Cable M. Suitable cable should have sufficient power to heat up the water within the required time.

This means that the power rate should at least be higher than the heat loss rating at $55^{\circ} \mathrm{C}$. However, 
the cable power rate does not need to be much higher than the heat loss rate, considering the very high starting power rate and too frequent on-off switch of the cable caused by. The results are shown in Table 6Table 6 and Table 7Table 7.

Table 6 Heat-up time for each pipe segment by Cable $\mathbf{R}$

\begin{tabular}{c|cccc}
\hline Segment & & \multicolumn{2}{c}{ Time $[\mathrm{h}]$} & \\
& Stainless steel Normal & Stainless steel Plus & PEX Normal & PEX Plus \\
\hline Basement 1 & 0.57 & 0.53 & 0.62 & 0.57 \\
Basement 2 & 0.90 & 0.83 & 1.07 & 0.90 \\
Ground floor & 0.50 & 0.47 & 0.53 & 0.51 \\
1st floor & 0.50 & 0.47 & 0.53 & 0.51 \\
2nd floor & 0.31 & 0.28 & 0.39 & 0.37 \\
3rd floor & 0.31 & 0.28 & 0.39 & 0.37 \\
4th floor & 0.31 & 0.28 & 0.39 & 0.37 \\
5th floor & 0.20 & 0.20 & 0.25 & 0.22 \\
\hline
\end{tabular}

Table 7 Heat-up time for each pipe segment by Cable M

\begin{tabular}{c|cccc}
\hline Segment & & \multicolumn{2}{c}{ Time $[\mathrm{h}]$} & \\
& Stainless steel Normal & Stainless steel Plus & PEX Normal & PEX Plus \\
\hline Basement 1 & 2.56 & 1.72 & 4.29 & 2.03 \\
Basement 2 & - & 2.68 & - & 3.27 \\
ground floor & 1.38 & 1.18 & 1.57 & 1.30 \\
1st floor & 1.38 & 1.18 & 1.57 & 1.30 \\
2nd floor & 0.90 & 0.66 & 1.06 & 0.92 \\
3rd floor & 0.90 & 0.66 & 1.06 & 0.92 \\
\hline
\end{tabular}




\begin{tabular}{c|cccc}
\hline 4th floor & 0.90 & 0.66 & 1.06 & 0.92 \\
5th floor & 0.68 & 0.41 & 0.71 & 0.52 \\
\hline
\end{tabular}

As the results show, the time taken to heat up DHW from $45^{\circ} \mathrm{C}$ to $55^{\circ} \mathrm{C}$ using Cable $\mathrm{R}$ ranged from 12 minutes to around 1 hour, while for Cable M, it was not possible in all segments. That is because the rate of heat loss at $55^{\circ} \mathrm{C}$ was greater than the power rate of the cable at that temperature, which means that the temperature of DHW in this case cannot reach $55^{\circ} \mathrm{C}$. In this study, therefore, Cable $\mathrm{R}$ was chosen to heat up the pipes in the basements, and all the other pipe segments were heated by Cable M.

3.4 Simulation results for the electric heat tracing system based under different control methods

\subsubsection{Dynamic working process of the electric tracing cable}

Figure 8Figure 8 shows the simulation results of how the tracing cable performed with/without thermostatic control. 


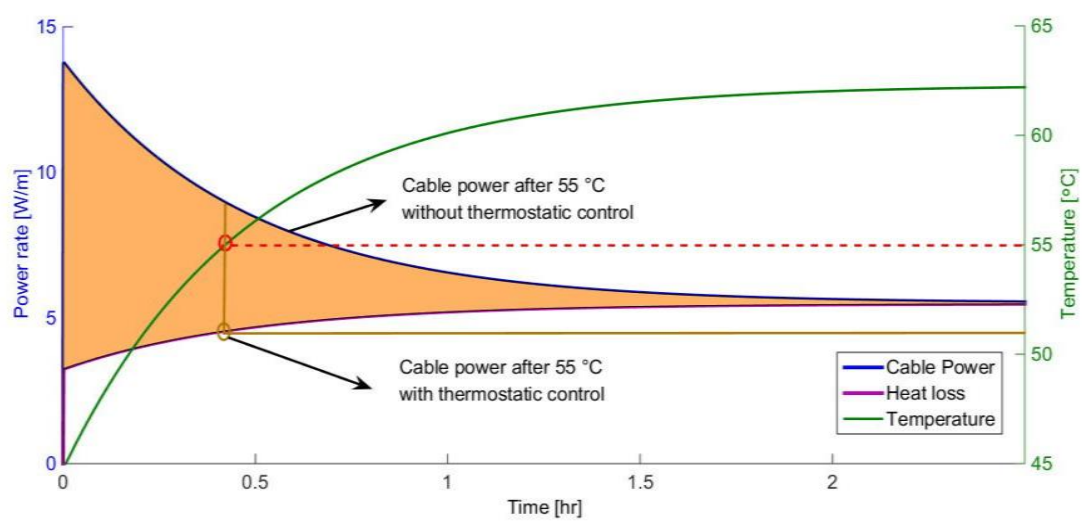

Figure 8 Dynamic working process of the tracing cable $M$ for stainless steel plus on $5^{\text {th }}$ floor with/without thermostatic control

As shown in the picture, since the tracing cable had the self-regulating function, the power rate is not a constant value, but decreased with temperature. In contrast, the heat loss rate increases with time. As a result, the DHW temperature increases non-linearly with time and reaches its plateau when the power rate and the heat loss rate balance. The area between the cable power rate and heat loss rate is the energy consumption for heating up the DHW. In a conventional system with DHW circulation, this energy is provided by the district heating completely. However, by using electric tracing cable, the supply temperature of district heating can be reduced, and part of the heat from district heating network can be saved.

If normal control method were applied, it would be impossible for the cable above the ground floor to reduce the power to balance the heat loss rate when DHW reaches $55{ }^{\circ} \mathrm{C}$, so the electricity consumption would be the whole area below the cable power curve. With smart control, the power can reduce to balance the heat loss rate as soon as $55^{\circ} \mathrm{C}$ is reached. The power consumption after that is the area below the brown line. As a result, overheating is avoided, saving both heat loss and heating energy. 


\subsubsection{Energy consumption of the electric heat tracing system in different scenarios}

This analysis was made on the stainless steel plus system, the energy performance of the electric heat tracing system was analysed for 6 scenarios according to different load profiles and control methods.

The results of each scenario are listed in Table 8Table 8.

Table 8 Total electricity consumption and electricity for covering heat loss in different scenarios when applying electric heat tracing

\begin{tabular}{|c|c|c|c|c|c|c|}
\hline & \multicolumn{2}{|c|}{$\begin{array}{c}\text { Load profile } 1 \\
\text { [kWh/year] }\end{array}$} & \multicolumn{2}{|c|}{$\begin{array}{l}\text { Load profile } 2 \\
\text { [kWh/year] }\end{array}$} & \multicolumn{2}{|c|}{$\begin{array}{c}\text { Real data } \\
{[\mathrm{kWh} / \text { year }]}\end{array}$} \\
\hline & $\begin{array}{c}\text { Total } \\
\text { electricity } \\
\text { consumption }\end{array}$ & $\begin{array}{l}\text { Heat } \\
\text { loss }\end{array}$ & $\begin{array}{c}\text { Total } \\
\text { electricity } \\
\text { consumption }\end{array}$ & $\begin{array}{l}\text { Heat } \\
\text { loss }\end{array}$ & $\begin{array}{c}\text { Total } \\
\text { electricity } \\
\text { consumption }\end{array}$ & $\begin{array}{l}\text { Heat } \\
\text { loss }\end{array}$ \\
\hline $\begin{array}{l}\text { Smart } \\
\text { control }\end{array}$ & 8960 & 4551 & 4179 & 2650 & 8895 & 3780 \\
\hline $\begin{array}{l}\text { Normal } \\
\text { control }\end{array}$ & 11286 & 5306 & 10467 & 3626 & 11294 & 4379 \\
\hline
\end{tabular}

* The source of Load profiles 1 and 2 is described in section 2.4 .

As shown in Table 8Table 8, compared with normal control, applying smart control saved $20.6 \%$, $60.1 \%$, and $21.2 \%$ on the total electricity consumption for the cases of Load profile 1 , Load profile 2 , and the real data, respectively. The heat loss was also reduced by approximately $14-27 \%$. That was because the smart control method helped avoid overheating of the pipes. Moreover, unnecessary power consumption was saved by switching off the heat tracing cable during draw-off periods. Thus, both cable power and heat loss were reduced. Additionally, cable power was used not only to cover 
the heat loss, but also to heat up hot water locally. The real data scenarios used only $50 \%$ of the cable power for covering the heat loss, in both control methods.

Another thing should be noticed of is that among different load profiles, the total electricity consumptions under the normal control method were very similar. But with the smart control method, the load profiles played an important role in the total power consumption. The difference between the Load profile1 and Load profile2 under the smart control method was almost $50 \%$. If the system has a high simultaneity factor, as in Load profile 1 in this case, the tracing cable has to heat up hot water for more intervals, which will undoubtedly lead to more power consumption. So the complex use of domestic hot water corresponds to the improvement of energy efficiency of for the electric heat tracing system.

\subsubsection{Comparison between the in-line circulation system and the electric heat tracing system}

The energy performances of all the different scenarios (as well as the in-line circulation system) are shown in Figure 9Figure 9. 


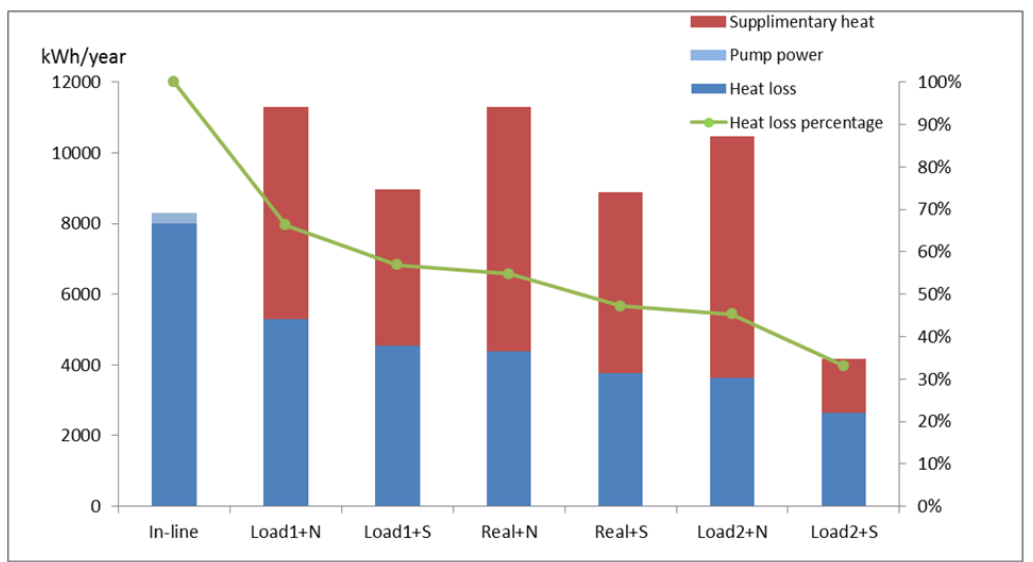

Figure 9 Comparison of annual energy consumption between circulation and electric heat tracing systems

*S- smart control, $\mathbf{N}$ - normal control

As shown in Figure 9Figure9, the total energy consumption of the in-line circulation system consisted of two parts: the heat loss covered by district heating network and a small amount of electricity for pumping power. The heat loss of the in-line circulation system, which was approximately $8000 \mathrm{kWh}$ per year, was greater than the heat loss in any of the electric heat tracing scenarios. Compared to the in-line circulation system, the heat loss reductions in the different electric heat tracing scenarios ranged from $34 \%-67 \%$. However, for the electric heat tracing system, a large proportion of the overall electricity consumption was used to heat up the DHW, which leads to higher overall energy consumption. Thus, only the scenario using Load profile 2 with smart control consumed less energy than the circulation system. According to the Danish Building Regulation (BR10 2010), the maximum amount of energy allowed for producing domestic hot water is $13 \mathrm{kWh} / \mathrm{m}^{2}$. Thus, the allowable overall DHW heat consumption was $46800 \mathrm{kWh} /$ year for the analysed building. The extra electricity by the electric heat tracing system for heating up domestic hot water only accounted for $3-15 \%$ of the standard value. But 
the district heating network only had to heat up hot water to $45^{\circ} \mathrm{C}$ instead of $60{ }^{\circ} \mathrm{C}$ for the circulation system. Thereby, a large amount of heating energy can be saved from the district heating network.

The annual operation cost for distributing DHW from the substation to the consumers was calculated for each scenario. For the in-line circulation scenario, the power consumption of the circulation pump was also included. With regard to the primary energy factor, the prices for district heating and electricity are assumed to $0.8 \mathrm{DKK} / \mathrm{kWh}$ and $2 \mathrm{DKK} / \mathrm{kWh}$, respectively. The economic performances of different scenarios are shown in Table 9Table 9.

Table 9 Annual operation cost for distributing DHW (in DKK) of the different scenarios

\begin{tabular}{cccccccc}
\hline & In-line & Load1+N & Load1+S & Real+N & Real+S & Load2+N & Load2+S \\
\hline Total operation & 6973 & 22572 & 17920 & 22588 & 17790 & 20933 & 8357 \\
cost & & & & & & & \\
Heat loss cost & 6401 & 10613 & 9103 & 8758 & 7559 & 7252 & 5300 \\
Heating energy & - & 4784 & 3527 & 5532 & 4092 & 5473 & 1223 \\
saving & & & & & & & \\
\hline
\end{tabular}

The savings of district heating energy by using electric heat tracing was calculated by multiplying the supplementary het by the district heating price $(0.8 \mathrm{DKK} / \mathrm{kWh}$ ann). As shown in Table 9Table 9 , almost half of the total costs of the electric heat tracing system were used to heat up the DHW. The costs for covering the heat loss were not significantly higher than that of the conventional system. Moreover, the district heating grid can save much energy because of the lower supply temperature. This means, it will be possible to make lower district heating price for the consumers, so that to compensate the extra expense by electricity. The break-even district heating price can be calculated by considering the total heat demand and electricity consumption. Take the "Real $+\mathrm{S}$ " scenario as an example, the overall heating demand according to the Danish Building Regulation is no more than 
$29.5 \mathrm{kWh} / \mathrm{m} 2 \mathrm{ann}$, while the annual electricity consumption is $8895 \mathrm{kWh}$ for the whole building. To give an even overall expense to the consumer, the district heating price should be no higher than 0.69 $\mathrm{DKK} / \mathrm{kWh}$.

\section{Conclusion}

This paper presents scenario analyses of electric heat tracing system as an alternative solution for supplying DHW with LTDH. A dynamic model was built to simulate the performance of electric heat tracing system under different scenarios which were described by different control strategies and DHW load profiles. The effect of different pipe materials and insulations were also analysed. The results were compared to an in-line circulation system.

- The pipe material had only a very slight influence on the total energy use (less than $8 \%$ ), but the use of better insulation (30\%-50\% thicker) made it possible to reduce power use by $10 \%$ and heat loss by $18 \%$.

- Smart control method based on real-time and thermostatic control had a significant impact on the system performance of the electric heat tracing system. Compared to the normal control method, smart control was able to save more than $20 \%$ of the total electricity consumption.

- The load profile played an important role in the energy performance of the electric heat tracing system under smart control method. The difference between Load profile 1 (with a high simultaneity factor) and Load profile 2 (with a low simultaneity factor) was as much as $50 \%$.

- Compared to the in-line circulation system, the electric heat tracing system saved $34-67 \%$ of the loss. The energy for heating up the water locally accounted for almost $50 \%$ of the total energy consumption of the electric heat tracing system. 
- The application of electric heat tracing system gives access to the implementation of LTDH. It is possible to compensate the extra cost caused by the cable power by lower district heating price, since the district heating grid can save much energy if LTDH is applied.

This study shows that both the comfort and safety requirements for DHW supply can be met by LTDH if combined with an electric tracing system. Electric tracing is thus a promising alternative method to realized LTDH when full renovation of the pipe network is not feasible or the space is very limited. Based on the results of this study, smart control is of great importance for energy conservation in electric tracing systems. Large multi-storey buildings with high variation in the DHW load are more appropriate to implement electric heat tracing system. In terms of the work in the future, the benefits caused by LTDH in the district heating network and heat production side should be investigated to give a more comprehensive overview.

\section{References}

Bøhm B (2013). Production and distribution of domestic hot water in selected Danish apartment buildings and institutions. Analysis of consumption, energy efficiency and the significance for energy design requirements of buildings. Energy Conversion and Management, 67:152-159.

BR10 (2010). Danish Building Regulations 2010. Copenhagen: The Danish Ministry of Economic and Business Affairs. \& Danish Enterprise and Construction Authority.

Ciesielski CA, Blaser MJ, Wang WLL (1984) Role of Stagnation and Obstruction of Water-Flow in Isolation of Legionella-Pneumophila from Hospital Plumbing. Applied and Environmental Microbiology, 48:984-987.

Commision Delegated Regulation (EU) of 18.2.2013 (2013). European Commission, Brussels DS439 (2009). Code of Practice for domestic water supply installations. Copenhagen. (in Danish).

DS452 (2013). Insulation of thermal installations. Charlottenlund: Danish standard (in Danish). DS/CEN/TR16355 (2012). Recommendations for prevention of Legionella growth in installations inside buildings conveying water for human consumption. Copenhagen: European committee for standardization.

Dyrelund A et al. (2010) Heat plan Denmark - Low Carbon Urban Heating. CTR FRB:23.

EWGLI group (2005). European Guidelines for Control and Prevention of Travel Associated Legionnaires' Disease. European Commission.

Geberit (2014). Mapress rustfrit systemrør. Available via DIALOG. http://catalog.geberit.com/public/product.aspx?cat=DK DK-da $1 \& \mathrm{ch}=218 \& \mathrm{p}=63766$. 
Grontmij (2013). A/S 2600 Golstrup. Available via DIALOG. http://www.grontmij.dk/en/services/energy-climate/district-heating/pages/default.aspx.

Accessed 24, June 2013.

Lund H, Werner S, Wiltshire R, Svendsen S, Thorsen JE, Hvelplund F, Mathiesen BV (2014). 4th Generation District Heating (4GDH). Energy, 68:1-11.

Olsen KH (2001). Legionellabekæmpelse med varmekabler. VVS BRUGSVAND, 2:20-22. (in Danish).

Reidhav C, Werner S (2008). Profitability of sparse district heating. Applied Energy, 85:867877.

Rockwool(2014a) (2014). Den lille tekniske, En guide til teknisk isolering af $r \varnothing r$ og installationer. Available via DIALOG. http://www.rockwoolrti.dk/files/RTI/rockwool den lille tekniske.pdf.

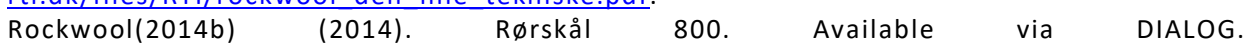
http://www.rockwool.dk/produkter/u/8052/vvs-isolering/roerskaal-800.

Uponor (2006). Håndbog for Uponor Brugsvandssystem PEX. Uponor A/S, Glostrup. Available via DIALOG. https://www.uponor.dk/ /media/countryspecific/denmark-b/d/downloadcentre/current/haandbook-vvs/s535-540 up vvs2010 udqaaede-quickman Ir.pdf?version=1. van der Kooij D, Veenendaal HR, Scheffer WJH (2005). Biofilm formation and multiplication of Legionella in a model warm water system with pipes of copper, stainless steel and crosslinked polyethylene. Water Research, 39:2789-2798.

Viega (2014). Smartloop inliner beregning. Available via DIALOG.

http://www.viega.dk/cps/rde/xbcr/dadk/smartloop inliner beregning.pdf.

\section{Tables}

Table $\underline{101}$ Period length and flow rate of different types of draw-off

\begin{tabular}{ccccc}
\hline & Hand Washing & Kitchen & Shower & Bathtub \\
\hline Period (min) & 3 & 2.5 & 5 & 10 \\
Flow rate (L/min) & 3 & 6 & 8.4 & 12 \\
\hline
\end{tabular}

Table $\underline{11} 2$ Pipe dimensions and insulation of in-line circulation system

\begin{tabular}{ccccc}
\hline Segment & $\begin{array}{c}\text { Apartments } \\
\text { supplied }\end{array}$ & Exterior pipe & Inline pipe & Insulation \\
Basement 1 & 12 & $42 \times 1.5$ & $14 \times 2$ & dimickness [mm] \\
Basement 2 & 24 & $54 \times 2.0$ & $14 \times 2$ & 40 \\
Ground floor & 12 & $42 \times 1.5$ & $14 \times 2$ & 30 \\
\hline
\end{tabular}




\begin{tabular}{lcccc}
\hline 1st floor & 10 & $42 \times 1.5$ & $14 \times 2$ & 30 \\
2nd floor & 8 & $42 \times 1.5$ & $14 \times 2$ & 30 \\
3rd floor & 6 & $42 \times 1.5$ & $14 \times 2$ & 30 \\
4th floor & 4 & $42 \times 1.5$ & $14 \times 2$ & 30 \\
5th floor & 2 & $35 \times 1.5$ & $14 \times 2$ & 30 \\
\hline
\end{tabular}

Table $\underline{12} z$ Pipe dimension and insulation of electric heat tracing systems

\begin{tabular}{c|ccc|ccc}
\hline \multirow{2}{*}{ Segment } & \multicolumn{3}{|c|}{ PEX pipes } & \multicolumn{3}{c}{ Stainless steel pipes } \\
\cline { 2 - 7 } & Pipe & Insulation & Insulation & Pipe & Insulation & Insulation \\
& Dimension & Normal & Plus & Dimension & Normal & Plus \\
\hline Basement 1 & $32 \times 4.4$ & 30 & 40 & $28 \times 1.2$ & 30 & 40 \\
Basement 2 & $40 \times 5.5$ & 30 & 50 & $35 \times 1.5$ & 30 & 50 \\
Ground & $32 \times 4.4$ & 30 & 40 & $28 \times 1.2$ & 30 & 40 \\
floor & & & & & & \\
1st floor & $32 \times 4.4$ & 30 & 40 & $28 \times 1.2$ & 30 & 40 \\
2nd floor & $28 \times 4.0$ & 30 & 40 & $22 \times 1.2$ & 20 & 40 \\
3rd floor & $28 \times 4.0$ & 30 & 40 & $22 \times 1.2$ & 20 & 40 \\
4th floor & $28 \times 4.0$ & 30 & 40 & $22 \times 1.2$ & 20 & 40 \\
5th floor & $22 \times 3.0$ & 20 & 40 & $18 \times 1.0$ & 20 & 40 \\
\hline
\end{tabular}

Table 4 Heat loss of in-line circulation system

\begin{tabular}{llclllllll}
\hline Basement1 & Basement2 & Ground & 1st & 2nd & 3rd & 4th & 5th \\
& & floor & Floor & Floor & Floor & Floor & Floor \\
\hline
\end{tabular}




\begin{tabular}{|c|c|c|c|c|c|c|c|c|}
\hline $\begin{array}{c}\text { Heat loss rate } \\
{[\mathrm{W} / \mathrm{m}]}\end{array}$ & 11.2 & 11.2 & 8.8 & 8.8 & 8.8 & 8.8 & 8.8 & 7.9 \\
\hline $\begin{array}{c}\text { Total heat } \\
\text { loss } \\
\text { [kWh/year }]\end{array}$ & & 8001 & & $\begin{array}{l}\text { Pun } \\
{[\mathrm{kV}}\end{array}$ & & & 286 & \\
\hline
\end{tabular}

Table $\underline{135}$ Heat loss at $55{ }^{\circ} \mathrm{C}$ of electric heat tracing systems with different pipe materials and insulations

\begin{tabular}{c|cccc}
\hline \multirow{2}{*}{ Segment } & & \multicolumn{3}{c}{ Heat loss at $55^{\circ} \mathrm{C}[\mathrm{W} / \mathrm{m}]$} \\
& Stainless steel & Stainless steel & PEX & PEX \\
& Normal & Plus & Normal & Plus \\
\hline Basement1 & 8.37 & 7.29 & 8.87 & 7.70 \\
Basement2 & 9.54 & 7.37 & 10.14 & 7.79 \\
Ground floor & 6.51 & 5.67 & 6.90 & 5.99 \\
1st Floor & 6.51 & 5.67 & 6.90 & 5.99 \\
2nd Floor & 6.86 & 5.01 & 6.38 & 5.57 \\
3rd Floor & 6.86 & 5.01 & 6.38 & 5.57 \\
4th Floor & 6.86 & 5.01 & 6.38 & 5.57 \\
5th Floor & 6.12 & 4.55 & 6.73 & 4.94 \\
\hline
\end{tabular}

Table 6 Heat-up time for each pipe segment by Cable $R$

\begin{tabular}{c|cccc}
\hline \multirow{2}{*}{ Segment } & \multicolumn{4}{|c}{ Time [h] } \\
& Stainless steel Normal & Stainless steel Plus & PEX Normal & PEX Plus \\
\hline Basement 1 & 0.57 & 0.53 & 0.62 & 0.57 \\
Basement 2 & 0.90 & 0.83 & 1.07 & 0.90 \\
\hline
\end{tabular}




\begin{tabular}{c|cccc}
\hline Ground floor & 0.50 & 0.47 & 0.53 & 0.51 \\
1st floor & 0.50 & 0.47 & 0.53 & 0.51 \\
2nd floor & 0.31 & 0.28 & 0.39 & 0.37 \\
3rd floor & 0.31 & 0.28 & 0.39 & 0.37 \\
4th floor & 0.31 & 0.28 & 0.39 & 0.37 \\
5th floor & 0.20 & 0.20 & 0.25 & 0.22 \\
\hline
\end{tabular}

Table 7 Heat-up time for each pipe segment by Cable M

\begin{tabular}{c|cccc}
\hline Segment & & \multicolumn{2}{c}{ Time $[\mathrm{h}]$} & \\
& Stainless steel Normal & Stainless steel Plus & PEX Normal & PEX Plus \\
\hline Basement 1 & 2.56 & 1.72 & 4.29 & 2.03 \\
Basement 2 & - & 2.68 & - & 3.27 \\
ground floor & 1.38 & 1.18 & 1.57 & 1.30 \\
1st floor & 1.38 & 1.18 & 1.57 & 1.30 \\
2nd floor & 0.90 & 0.66 & 1.06 & 0.92 \\
3rd floor & 0.90 & 0.66 & 1.06 & 0.92 \\
4th floor & 0.90 & 0.66 & 1.06 & 0.92 \\
5th floor & 0.68 & 0.41 & 0.71 & 0.52 \\
\hline
\end{tabular}

Table 148 Total electricity consumption and electricity for covering heat loss in different scenarios when applying electric heat tracing

\begin{tabular}{|c|c|c}
\hline $\begin{array}{c}\text { Load profile 1 } \\
{[\mathrm{kWh} / \text { year }]}\end{array}$ & $\begin{array}{c}\text { Load profile 2 } \\
{[\mathrm{kWh} / \text { year }]}\end{array}$ & Real data \\
& {$[\mathrm{kWh} /$ year $]$} \\
\hline
\end{tabular}




\begin{tabular}{|c|c|c|c|c|c|c|}
\hline & $\begin{array}{c}\text { Total } \\
\text { electricity } \\
\text { consumption }\end{array}$ & $\begin{array}{c}\text { Heat } \\
\text { loss }\end{array}$ & $\begin{array}{c}\text { Total } \\
\text { electricity } \\
\text { consumption }\end{array}$ & $\begin{array}{c}\text { Heat } \\
\text { loss }\end{array}$ & $\begin{array}{c}\text { Total } \\
\text { electricity } \\
\text { consumption }\end{array}$ & $\begin{array}{c}\text { Heat } \\
\text { loss }\end{array}$ \\
\hline $\begin{array}{l}\text { Smart } \\
\text { control }\end{array}$ & 8960 & 4551 & 4179 & 2650 & 8895 & 3780 \\
\hline $\begin{array}{l}\text { Normal } \\
\text { control }\end{array}$ & 11286 & 5306 & 10467 & 3626 & 11294 & 4379 \\
\hline
\end{tabular}

* The source of Load profiles 1 and 2 is described in section 2.4.

Table 159 Annual operation cost for distributing DHW (in DKK) of the different scenarios

\begin{tabular}{cccccccc}
\hline & In-line & Load1+N & Load1+S & Real+N & Real+S & Load2+N & Load2+S \\
\hline Total operation & 6973 & 22572 & 17920 & 22588 & 17790 & 20933 & 8357 \\
cost & & & & & & & \\
Heat loss cost & 6401 & 10613 & 9103 & 8758 & 7559 & 7252 & 5300 \\
Heating energy & - & 4784 & 3527 & 5532 & 4092 & 5473 & 1223 \\
saving & & & & & & & \\
\hline
\end{tabular}

\section{Figure Captions}

Figure 1 Schematics of conventional system with DHW circulation and electric heat tracing system

Figure 2 Typical load profile of European flats from EU directive

Figure 3 Stochastically-distributed load profile with time (hr) and flow rate (L/min)

Figure 4 Measured draw-off profile in a Danish multi-storey building with time (hr) and flow rate (L/min)

Figure 5 Self-regulation function of the electric tracing cables

Figure 6 Matlab model of electric tracing system with smart control 
Figure 7 Heat loss rates of in-line circulation system and electric heating tracing systems on different floors

Figure 8 Dynamic working process of the tracing cable $M$ for stainless steel plus on $5^{\text {th }}$ floor with/without thermostatic control

Figure 9 Comparison of annual energy consumption between circulation and electric heat tracing systems

*S- smart control, N- normal control

\section{Figures}

Figure 1

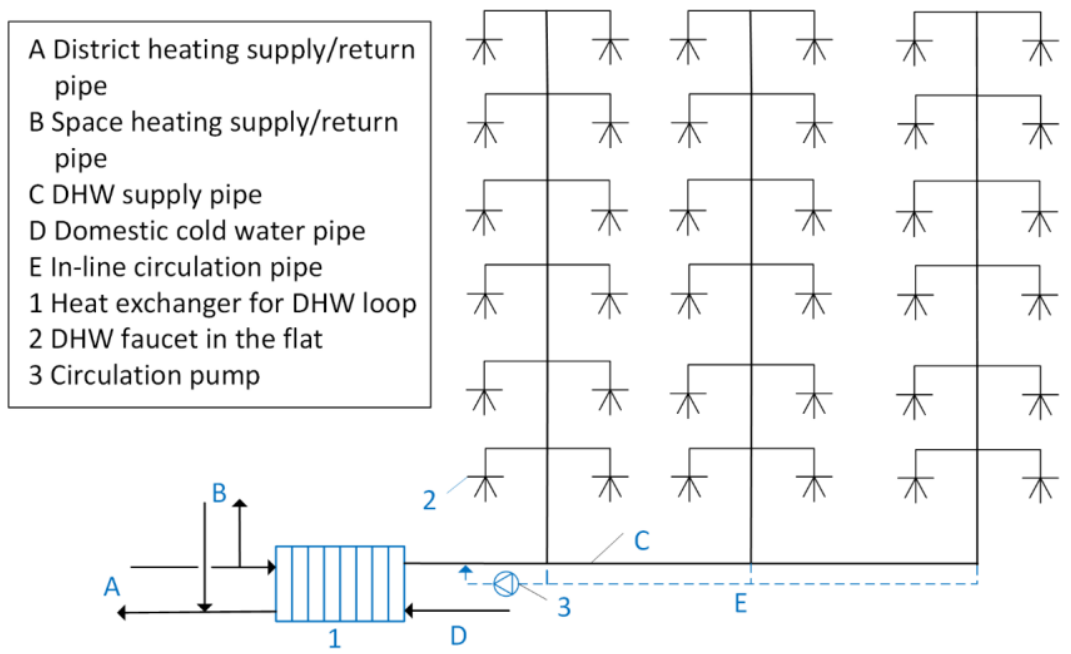

(a) 


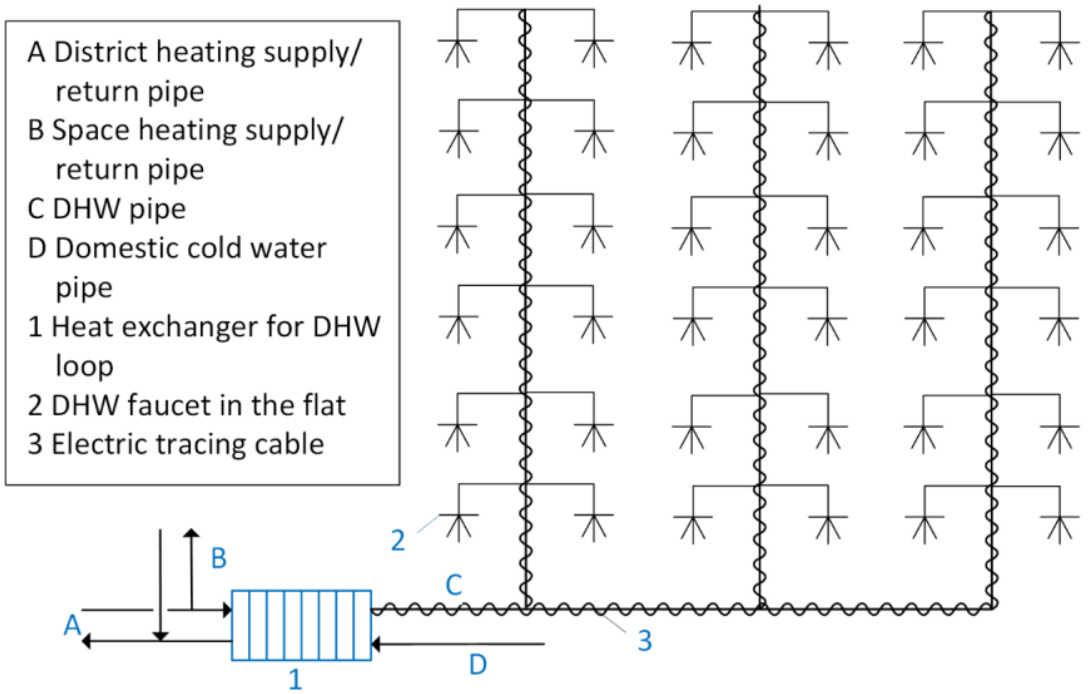

(b)

Figure 2

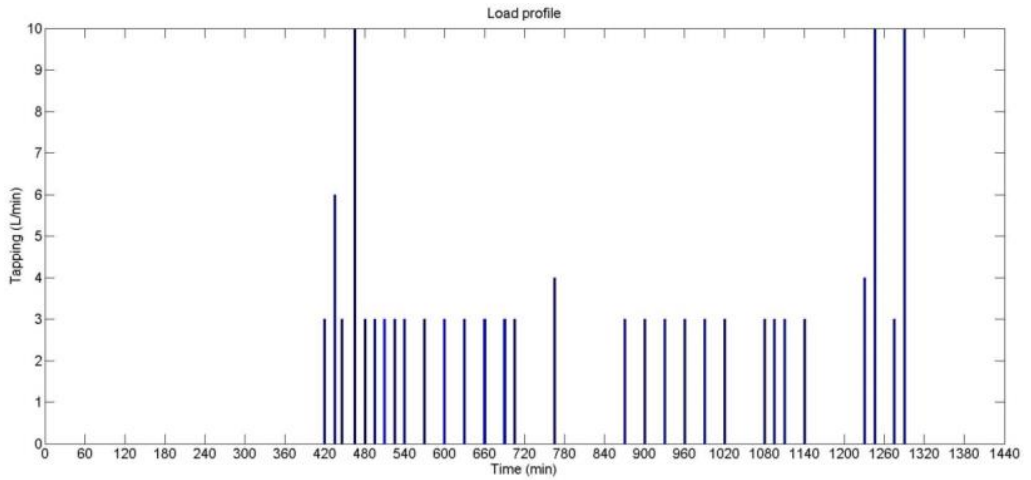

Figure 3 

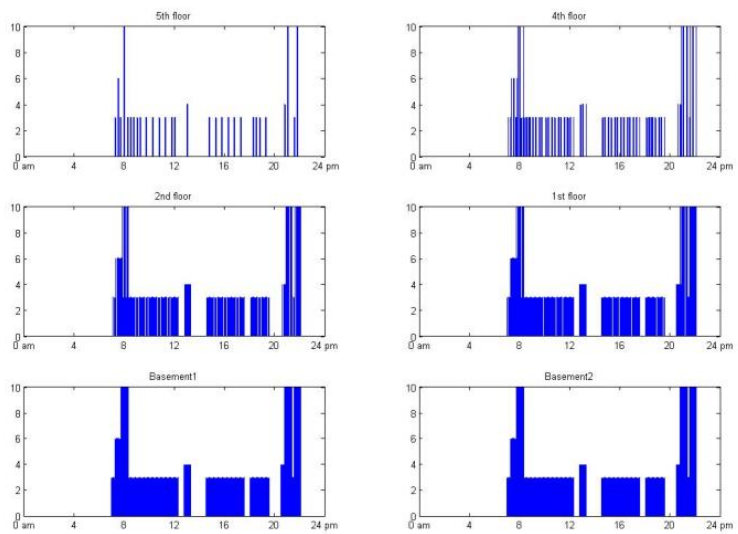

Figure 4
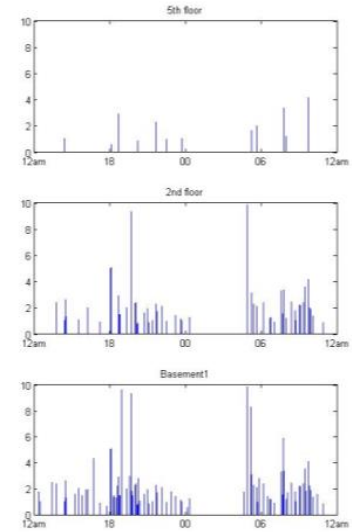

Figure 5
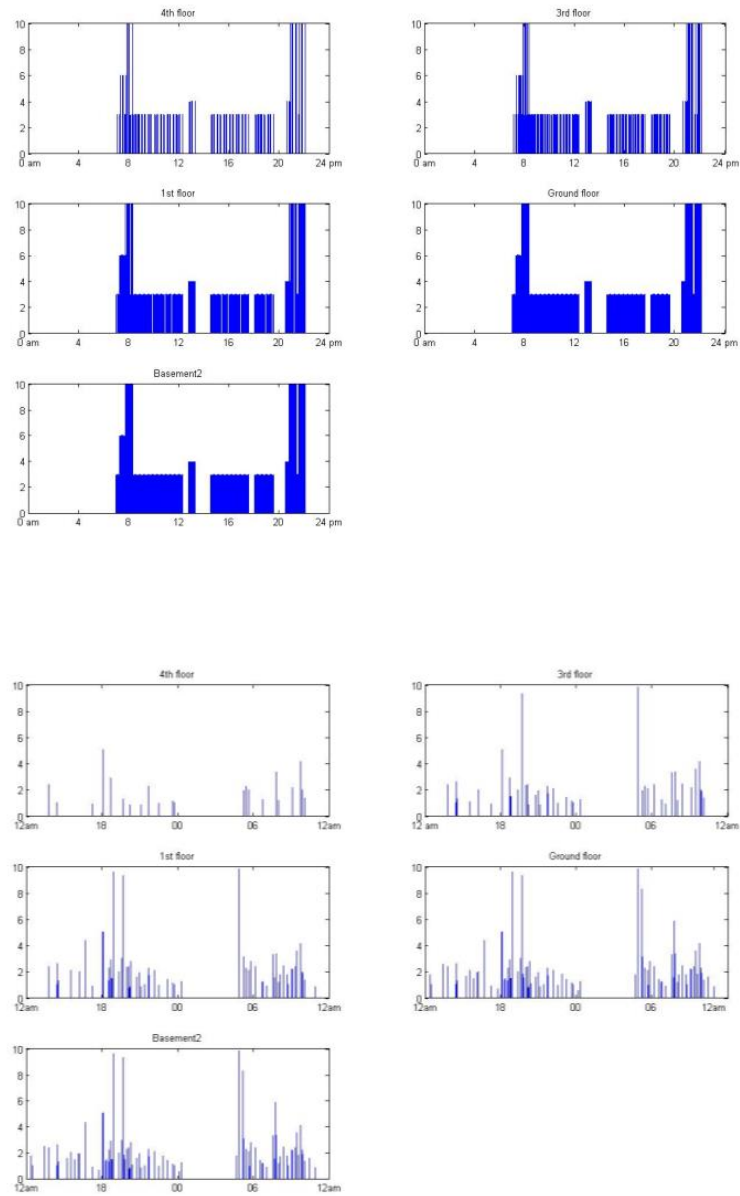


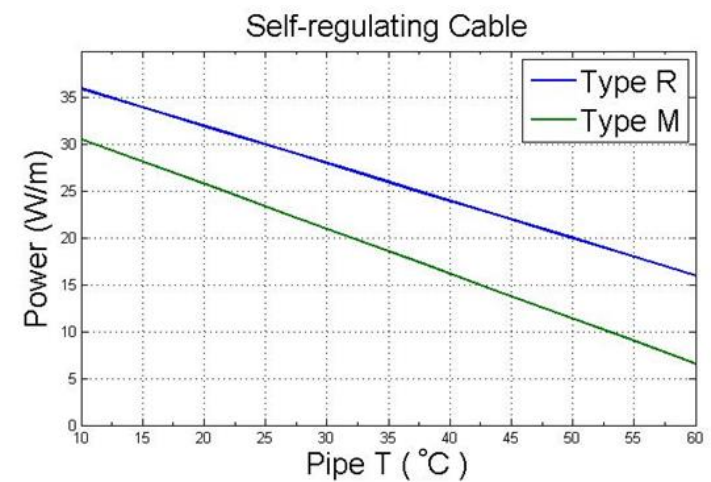

Figure 6

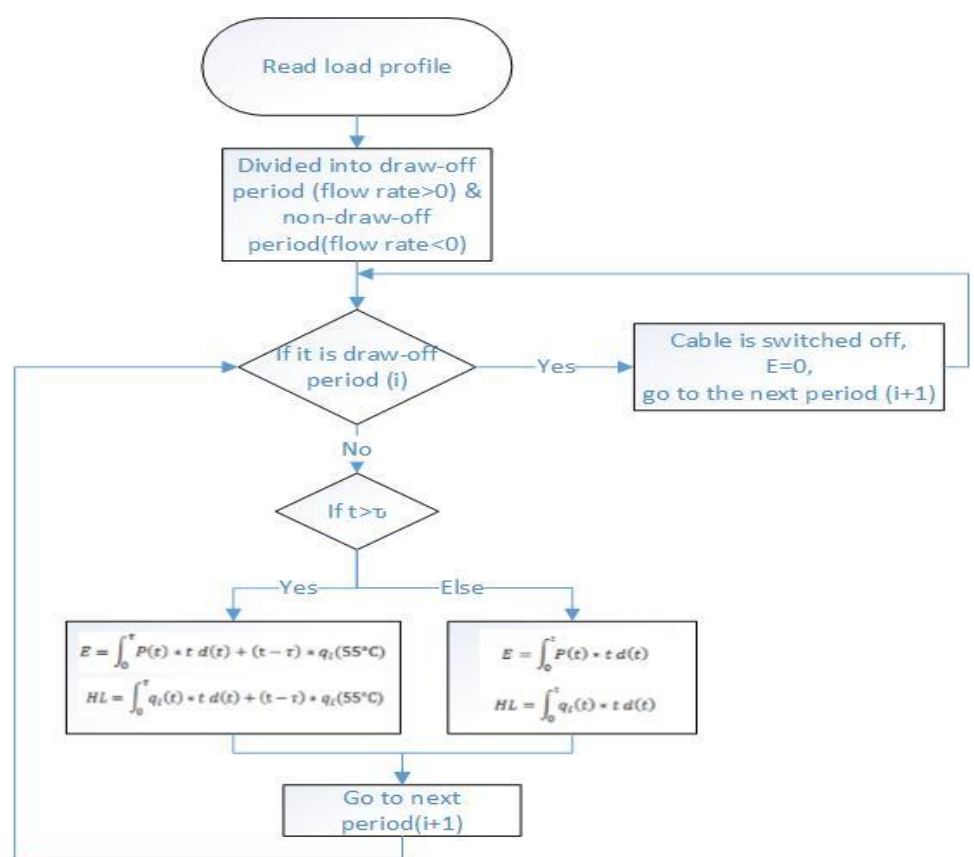

Figure 7 


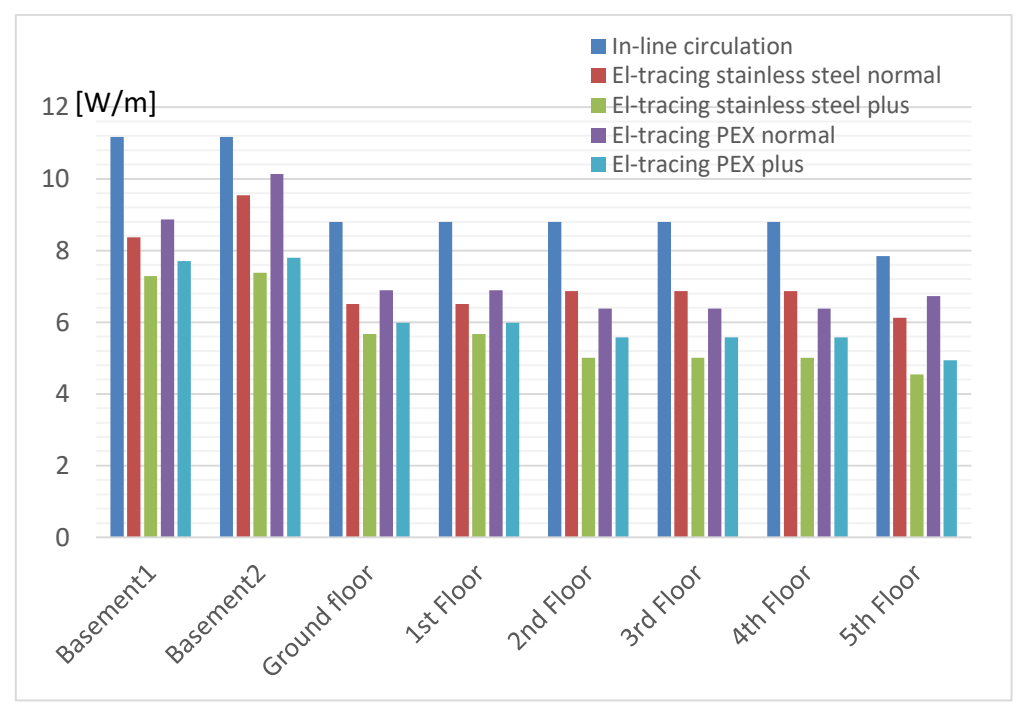

Figure 8

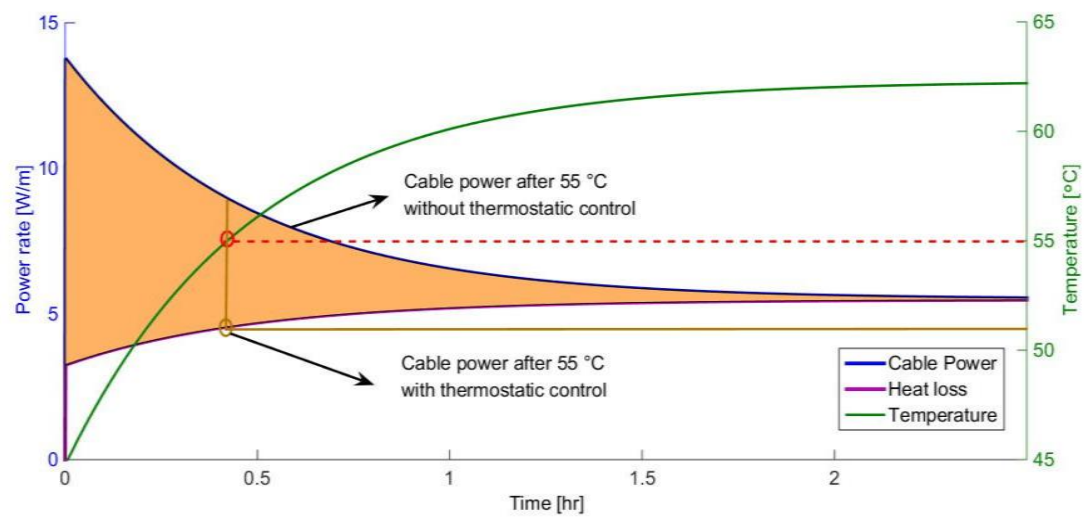

Figure 9 


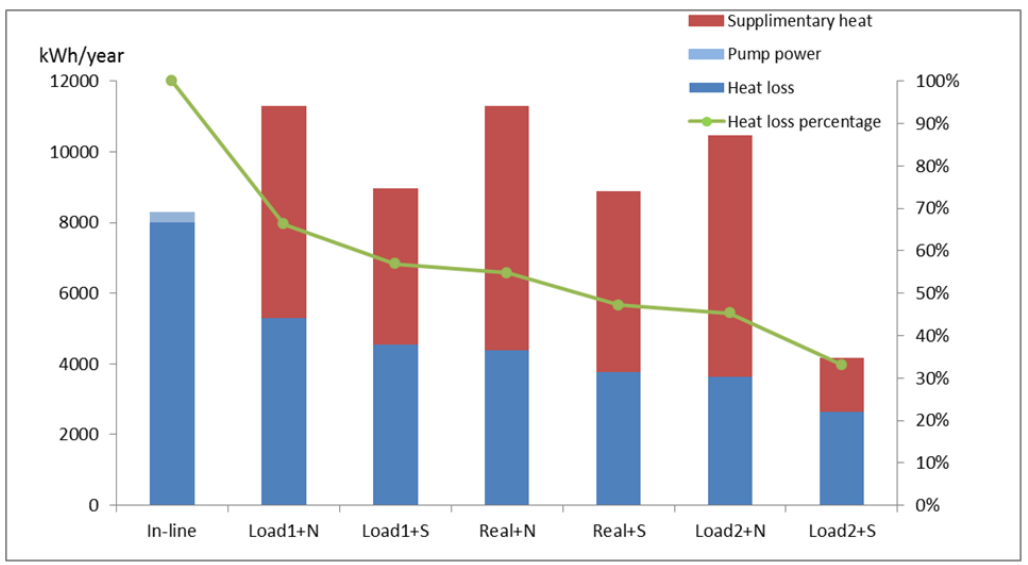

